\title{
COVID-19 Recommendations for Patients with Cancer: The post-COVID-19 Era
}

\author{
Nabil Ismaili ${ }^{1,2}$ (1) \\ Accepted: 21 July 2020 / Published online: 15 August 2020 \\ (C) Springer Nature Switzerland AG 2020
}

\begin{abstract}
Despite the extent of the COVID-19 infection worldwide, the impact of the pandemic in our country remains low thanks to containment measures. On July 11, 2020, the spread of the virus in Morocco has caused more than 15,000 cases and 243 deaths. It is important to note that cancer patients are at high risk of developing COVID-19 disease. However, little changes have been made in our clinical practice in cancer management. Medical care aims are to ensure optimal treatment while minimizing the risk of COVID-19 transmission. Management should be discussed in a multidisciplinary team meeting, and any decision made, particularly influenced by the context of the COVID-19 pandemic, should be discussed and shared with the patient. In this article, we summarize our practical recommendations and how we prioritize cancer patient care during the post-COVID-19 phase.
\end{abstract}

Keywords COVID- $19 \cdot$ Cancer $\cdot$ Surgery $\cdot$ Chemotherapy $\cdot$ Radiotherapy $\cdot$ Follow-up

\section{Introduction}

COVID-19 outbreak is a major health problem caused by a novel infectious disease (SARS-CoV-2 coronavirus) that appeared in December 2019 in the city of Wuhan in China.

Today, more than 12 million of COVID-19 cases have been confirmed worldwide, including more than 500,000 deaths. In Morocco, the first case of COVID-19 was identified on March 2, 2020, with a progressive increase to reach 15,443 cases on July 11. Cancer patients, mainly those who have received surgery or chemotherapy, are more likely to develop COVID-19 infection and to develop severe forms of the disease. It is important to note that frail, elderly, or patients with chronic diseases such as heart disease, diabetes, and chronic respiratory syndromes are at higher risk $(\times 3.5$ to 5 times $)$ of developing severe forms of the infection [1]. During the COVID-19 pandemic, national and international societies recommend continuing the management of cancer patients

This article is part of the Topical Collection on COVID-19

Nabil Ismaili

ismailinabil@yahoo.fr

1 Department of Medical Oncology, Cheick Khalifa International University Hospital, Casablanca, Morocco

2 Faculty of Medicine, Mohammed VI University of Health Sciences (UM6SS), Casablanca, Morocco despite the spread of the virus in the world. They established guidelines to adapt patient care and to limit the risk of contamination by the virus while preserving their chances of recovery [2-7] (http://smc.ma/recommandation-cancer-etcovid-19-smc/). For example, Table 1 summarizes special recommendations implemented for patients diagnosed with breast cancer during the COVID-19 pandemic [4]. In the present paper we summarize our recommendations for patients with cancer during the post-COVID-19 phase.

\section{Post-COVID-19 Era}

The post-COVID-19 era requires the implementation of new recommendations for the management of cancer patients that may be applicable until the end of 2020 - beginning of 2021. In short term, it is necessary to adapt medical care to the regional health environment, according to availability of medical and non-medical staff and equipment resources, which implies that the recommendations made should be adapted to the particularity of each region and each establishment [8].

During the post-COVID-19 phase, all patients should be considered as COVID-19 positive until proven otherwise. Thus, a national strategy for screening of COVID-19 infection should be considered before admission of patients in cancer centers, to protect cancer patients and medical staff from COVID-19 disease $[6,8]$. 
Table 1 Recommendations for breast cancer management during the COVID-19 outbreak

\begin{tabular}{|c|c|c|c|c|c|}
\hline Setting & Priority & & & & Multidisciplinary management \\
\hline Screening and diagnosis & Global & Surgery & $\mathrm{CT}$ & RT & \\
\hline $\begin{array}{l}\text { ACR4/5 lesion on } \\
\text { mammogram/echography }\end{array}$ & $\mathrm{H}$ & - & - & - & Proceed with biopsy for diagnosis without delay. \\
\hline Routine screening & $\mathrm{L}$ & - & - & - & $\begin{array}{l}\text { It is preferable to postpone screening mammogram } \\
\text { during the COVID-19 pandemic. }\end{array}$ \\
\hline \multicolumn{6}{|l|}{ Abnormal results } \\
\hline High-grade cancer & $\mathrm{H}$ & $\mathrm{H}$ & $\mathrm{H}$ & $\mathrm{H}$ & Start optimal treatment within 2 months. \\
\hline Low-grade cancer & $\mathrm{L}$ & $\mathrm{M}$ & $\mathrm{L}$ & $\mathrm{L}$ & Postpone surgery by $3-6$ months \\
\hline CIS & $\mathrm{L}$ & $\mathrm{L}$ & - & $\mathrm{L}$ & $\begin{array}{l}\text { Surgery could be deferred until the pandemic is over. } \\
\text { RT may be omitted for patients with CIS with good } \\
\text { prognosis (age }>40 \text { years, tumors }<2.5 \mathrm{~cm} \text {, low and } \\
\text { intermediate grade, and sufficient surgical margins } \geq 2 \mathrm{~mm} \text { ). }\end{array}$ \\
\hline \multicolumn{6}{|r|}{ 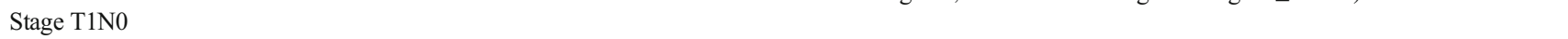 } \\
\hline HER2+ & $\mathrm{H}$ & $\mathrm{H}$ & $\mathrm{H}$ & M & $\begin{array}{l}\text { Conservative surgery first followed by adjuvant CT } \\
\text { and RT. Adjuvant trastuzumab may be shortened } \\
\text { from } 12 \text { to } 6 \text { months. Consider the Tolaney regimen } \\
\text { (weekly paclitaxel for } 12 \text { weeks plus three weekly } \\
\text { trastuzumab) to shorten CT duration. }\end{array}$ \\
\hline TNBC & $\mathrm{H}$ & $\mathrm{H}$ & $\mathrm{H}$ & M & $\begin{array}{l}\text { Conservative surgery first followed by adjuvant CT } \\
\text { and RT. Prefer sequential regimen based on doxorubicine } \\
\text { (or epirubicine)/cyclophosphamide every } 3 \text { weeks for } 4 \\
\text { cycles followed by docetaxel } 100 \mathrm{mg} / \mathrm{m}^{2} \text { every } 3 \\
\text { weeks for } 4 \text { cycles (with GCSF). }\end{array}$ \\
\hline Luminal B & M & M & M & M & $\begin{array}{l}\text { Conservative surgery first, then the management should } \\
\text { be discussed on a case-by-case basis. Favor adjuvant } \\
\text { chemotherapy using three weekly regimens such as docetaxel } \\
75 \mathrm{mg} / \mathrm{m}^{2} / \text { cyclophosphamide/GCSF for } 4-6 \text { cycles every } 3 \\
\text { weeks. Adjuvant RT should be recommended. For patients with } \\
\text { pT1/T2N0 disease, consider RT in the case of high-risk factors (LVI, high grade, } \\
\text { positive margins, } \\
\text { low-level hormone receptor). }\end{array}$ \\
\hline Luminal A & $\mathrm{L}$ & $\mathrm{L}$ & - & $\mathrm{L}$ & $\begin{array}{l}\text { Start with neoadjuvant endocrine therapy for } 6 \text { months } \\
\text { then proceed with surgery. For frail/elderly women with } \\
\text { good prognosis factors (grades } 1-2, \mathrm{HR}+\text {, tumors }<3 \\
\mathrm{~cm} \mathrm{~N}-\text {, HER } 2-\text { ) consider ultrahypo-fractionated schemes } \\
\text { of RT ( } 26-27 \text { Gy for } 5 \text { fractions). }\end{array}$ \\
\hline \multicolumn{6}{|l|}{ Stage $\mathrm{T} 2$ or $\mathrm{N}$ positive } \\
\hline HER2+ & $\mathrm{H}$ & $\mathrm{H}$ & $\mathrm{H}$ & M & $\begin{array}{l}\text { Start with neoadjuvant chemotherapy without delay followed } \\
\text { by surgery then RT. Use neoadjuvant pertuzumab/trastuzumab } \\
\text { /docetaxel regimen for } 6 \text { cycles plus GCSF. }\end{array}$ \\
\hline TNBC & $\mathrm{H}$ & $\mathrm{H}$ & $\mathrm{H}$ & M & $\begin{array}{l}\text { Start with neoadjuvant chemotherapy without delay followed } \\
\text { by surgery then RT. }\end{array}$ \\
\hline Luminal B & M & M & M & M & $\begin{array}{l}\text { Prefer surgery first within } 2 \text { months followed by adjuvant CT f } \\
\text { or } 6 \text { cycles, RT, and ET. }\end{array}$ \\
\hline Lumina A & $\mathrm{L}$ & $\mathrm{L}$ & $\mathrm{L}$ & $\mathrm{L}$ & $\begin{array}{l}\text { It is appropriate to start with neoadjuvant ET. Postpone surgery } \\
\text { for } 3 \text { to } 6 \text { months. }\end{array}$ \\
\hline \multicolumn{6}{|l|}{ Stage T3/T4 and or N2/N3 } \\
\hline HER2+ BC, TNBC, and luminal B & $\mathrm{H}$ & $\mathrm{H}$ & $\mathrm{H}$ & $\mathrm{H}$ & $\begin{array}{l}\text { Start with neoadjuvant chemotherapy without delay then proceed } \\
\text { with surgery and RT. }\end{array}$ \\
\hline Luminal A & M & M & M & M & $\begin{array}{l}\text { Discuss management on case-by-case basis: neoadjuvant ET } \\
\text { should be preferred. }\end{array}$ \\
\hline $\begin{array}{l}\text { Luminal A BC in women }>65 \text { years } \\
\text { or frail women with significant } \\
\text { comorbidities }\end{array}$ & $\mathrm{L}$ & $\mathrm{L}$ & $\mathrm{L}$ & $\mathrm{L}$ & It is preferable to start with ET. \\
\hline \multicolumn{6}{|l|}{ Metastatic disease } \\
\hline HER2+ & $\mathrm{H}$ & - & $\mathrm{H}$ & - & $\begin{array}{l}\text { Start with chemotherapy without delay. Prefer pertuzumab/trastuzumab } \\
\text { /docetaxel for } 6 \text { cycles (plus GCSF). }\end{array}$ \\
\hline TNBC & $\mathrm{H}$ & - & $\mathrm{H}$ & - & $\begin{array}{l}\text { Start with chemotherapy without delay. Prefer monotherapies with } \\
\text { capecitabine or cyclophosphamide for patients previously treated } \\
\text { with anthracyclines and taxanes. }\end{array}$ \\
\hline $\begin{array}{l}\text { Emergencies such as spinal cord } \\
\text { compression } \\
\text { and bleeding }\end{array}$ & $\mathrm{H}$ & $\mathrm{H}$ & - & $\mathrm{H}$ & $\begin{array}{l}\text { Consider radiotherapy to control symptoms. Consider RT for palliation } \\
\text { for pain/symptoms persistent despite optimal medications. }\end{array}$ \\
\hline Hormone dependent with visceral crisis & $\mathrm{H}$ & - & M & - & Prefer chemotherapy \\
\hline
\end{tabular}


Table 1 (continued)

\begin{tabular}{|c|c|c|c|}
\hline Setting & Priority & & Multidisciplinary management \\
\hline $\begin{array}{l}\text { Hormone-dependent disease without } \\
\text { visceral crisis }\end{array}$ & M & $\mathrm{L}$ & $\begin{array}{l}\text { Prefer ET. Consider CDK4/6 inhibitor plus aromatase inhibitor } \\
\text { for patients with no significant comorbidities (pulmonary disease). } \\
\text { CDK4/6 inhibitor may be differed if the likelihood of tumor control } \\
\text { with aromatase inhibitor is high. Avoid CDK4/6 inhibitors in } \\
\text { frail and elderly women. }\end{array}$ \\
\hline \multicolumn{4}{|l|}{ Follow-up } \\
\hline Follow-up after curative treatments & $\mathrm{L}$ & - & Follow-up may be postponed based on the level of risk for recurrence. \\
\hline $\begin{array}{l}\text { Follow-up during chemotherapy for } \\
\text { advanced disease }\end{array}$ & M & - & $\begin{array}{l}\text { For asymptomatic patients, routine radiological workup may be deferred } \\
\text { by } 8-12 \text { weeks. Defer routine visit during ET and oral CT; use } \\
\text { teleconsultation for prescription renewal. }\end{array}$ \\
\hline
\end{tabular}

$C T$, chemotherapy; $R T$, radiotherapy; $E T$, endocrine therapy. $H$, high priority: patients have disease requiring urgent treatment; $M$, medium priority: patients have disease that do not require immediate management but treatment should be started before the pandemic is over; $L$, low priority: patients have diseases that do not require immediate standard treatment and treatment may be safely postponed until crisis resolves

In addition, caution should be undertaking, as the epidemiological situation today will not be the same in the upcoming weeks.

\section{General Recommendations}

It is recommended to follow the same measures established by the WHO during COVID-19 era to protect cancer patients from COVID-19 infection (https://www.who.int/ emergencies/diseases/novel-coronavirus-2019):

- Washing hands frequently with an alcohol-based disinfectant or with soap and water.

- Maintaining a social distance of at least $1 \mathrm{~m}$ between patient and anyone who coughs or sneezes.

- Avoid touching the eyes, nose, and mouth.

- Compulsory wearing a mask.

- In case of fever, cough, and breathing difficulties, consulting a doctor early.

- Stay informed and follow the advice given by professionals, Ministry of Health and local authorities, as they can provide reliable information on the spread of COVID19 in the region.

On the other hand, it is recommended to respect the general post-COVID-19 measures established by the WHO (https:// www.who.int/emergencies/diseases/novel-coronavirus2019):

- Compliance with barrier measures.

- Testing, isolating each suspected case, then referring them to COVID-19 positive dedicated units.

- Implementing preventive measures to protect patients and caregivers.

- Educating caregivers and patients about the new standard measures.
Prevention of risks of contamination by suspect cases in cancer centers should be based on a systematic evaluation of clinical symptoms suggestive of COVID-19 disease, temperature taking at the entrance of the establishment, on a PCR test, and possibly coupled with a chest CT scan and serologies, depending on availability, in addition to biological workup to evaluate eosinopenia, lymphopenia, and increased of inflammation parameters [8].

Educating patients about the new context, the risk-benefit balance, the existence of a prioritization system for cancer care is an essential prerequisite (following the priorities proposed in Table 2).

The decision on the priorities for surgery should be undertaking in a multidisciplinary team (MDT) meeting in accordance with recommendations established by national and international societies $[3,4,7,8]$. The possibility of adapting the treatment sequence will depend on the disease stage and the acceptable time to defer surgery. Postponing surgery should only be considered in the case of difficulties to access to operating rooms in case of occupancy of the structure by COVID-19 patients.

General recommendations to limit contamination of patients in cancer centers while maintaining the chances of appropriate care [3-5, 7-9] are as follows:

- Prioritize teleconsultations as much as possible.

- Limit accompanying persons.

- Limit unnecessary hospitalizations.

- Postpone treatment of non-invasive cancers and localized low-grade cancers for 6-12 weeks.

- Favor chemotherapy protocols administered every 3 weeks.

- Systematic use of granulocyte colony-stimulating factors (GCSF) to prevent severe neutropenia in case of risk greater than $10 \%$.

- Prioritize oral therapies (hormone therapy and oral chemotherapy) as much as possible. 
Table 2 Recommendations for multidisciplinary management of cancer patients by priority during the post-COVID-19 phase

\begin{tabular}{|c|c|c|c|c|c|}
\hline Clinical setting & Priority & & & & Proposed multidisciplinary management \\
\hline Diagnostic & Global & Surgery & CT & RT & \\
\hline $\begin{array}{l}\text { Suspected cancer (breast, lung, } \\
\text { cervix, colon, stomach, ovary, etc.) }\end{array}$ & $\mathrm{H}$ & - & - & - & Immediate diagnostic procedure without delay. \\
\hline Early detection and diagnosis & $\mathrm{L}$ & - & - & - & $\begin{array}{l}\text { Screening and early diagnosis procedures may } \\
\text { be delayed by } 3 \text { months. }\end{array}$ \\
\hline In the case of diagnosis of cancer & Global & Surgery & CT & RT & Proposed multidisciplinary management. \\
\hline High- or intermediate-grade cancer & $\mathrm{H}$ & $\mathrm{H}$ & $\mathrm{H}$ & $\mathrm{H}$ & Start optimal treatment without delay. \\
\hline Low-grade cancer & $\mathrm{L}$ & M & $\mathrm{L}$ & $\mathrm{L}$ & Postpone treatment for 3 months. \\
\hline Carcinoma in situ (cervix, breast, bladder) & $\mathrm{L}$ & $\mathrm{L}$ & - & $\mathrm{L}$ & Surgery may be postponed for 3 months. \\
\hline Low risk early stage & Global & Surgery & CT & RT & Proposed multidisciplinary management. \\
\hline $\begin{array}{l}\text { Early operable cancers (breast, lung, } \\
\text { cervix, colon, stomach, etc.) }\end{array}$ & M & $\mathrm{H}$ & M & $\mathrm{M}$ & $\begin{array}{l}\text { Start with surgery first without delay, then } \\
\text { according to the standard recommendations, } \\
\text { chemotherapy then radiotherapy. Prefer } \\
\text { chemotherapy protocols administered } \\
\text { every } 3 \text { weeks whenever possible. Favor } \\
\text { hypo-fractionated radiotherapy regimens. }\end{array}$ \\
\hline Frail patients not eligible for surgery & M & M & M & $\mathrm{H}$ & $\begin{array}{l}\text { Substitute surgical treatment with radiotherapy } \\
\text { (lung cancer, prostate cancer, etc.) }\end{array}$ \\
\hline Hormone-dependent cancers & $\mathrm{L}$ & $\mathrm{L}$ & $\mathrm{L}$ & $\mathrm{L}$ & Consider primary hormone therapy (breast cancer). \\
\hline High risk early stage & Global & Surgery & $\mathrm{CT}$ & RT & Proposed multidisciplinary management. \\
\hline $\begin{array}{l}\text { Breast cancer, stomach cancer, } \\
\text { lung cancer ... }\end{array}$ & $\mathrm{H}$ & $\mathrm{H}$ & $\mathrm{H}$ & $\mathrm{H}$ & $\begin{array}{l}\text { Start with chemotherapy to delay surgery. } \\
\text { Use three weekly regimens plus GCSF. }\end{array}$ \\
\hline Frail patients not eligible for surgery & $\mathrm{H}$ & - & $\mathrm{H}$ & $\mathrm{H}$ & $\begin{array}{l}\text { Substitute surgical treatment with radiotherapy } \\
\text { (lung cancer, prostate cancer, } \\
\text { bladder cancer, etc.) }\end{array}$ \\
\hline $\begin{array}{l}\text { Hormone-sensitive cancers (breast } \\
\text { cancer, prostate cancer) }\end{array}$ & M & $\mathrm{H}$ & M & $\mathrm{H}$ & $\begin{array}{l}\text { Discuss first treatment with hormone therapy } \\
\text { to delay surgery and radiation therapy. }\end{array}$ \\
\hline Locally advanced stages & Global & Surgery & CT & RT & Proposed multidisciplinary management. \\
\hline $\begin{array}{l}\text { Locally advanced breast cancer, lung } \\
\text { cancer, cervical cancer, etc. }\end{array}$ & $\mathrm{H}$ & M & $\mathrm{H}$ & $\mathrm{H}$ & $\begin{array}{l}\text { Start treatment without delay. } \\
\text { Start chemotherapy in locally advanced } \\
\text { breast cancer, start radio-chemotherapy } \\
\text { in lung and cervical cancer, etc.... } \\
\text { Start with chemotherapy in locally advanced } \\
\text { ovarian cancer. }\end{array}$ \\
\hline Hormone-sensitive cancers & $\mathrm{H}$ & M & M & M & $\begin{array}{l}\text { Neoadjuvant ET may be considered } \\
\text { (breast cancer, prostate cancer). }\end{array}$ \\
\hline $\begin{array}{l}\text { Hormone-sensitive cancers in patients } \\
\text { over the age of } 70 \text {, with comorbidities }\end{array}$ & M & $\mathrm{L}$ & $\mathrm{L}$ & $\mathrm{L}$ & $\begin{array}{l}\text { It is preferable to start with ET (breast } \\
\text { cancer, prostate cancer, endometrial cancer). }\end{array}$ \\
\hline Metastatic stages & Global & Surgery & CT & RT & Proposed multidisciplinary management. \\
\hline High-grade cancers, rapidly evolving & $\mathrm{H}$ & - & $\mathrm{H}$ & - & $\begin{array}{l}\text { Start with chemotherapy without delay. } \\
\text { Use GCSF if the risk of neutropenia is } \\
\text { greater than } 10 \% \text {. }\end{array}$ \\
\hline $\begin{array}{l}\text { Emergencies like HTIC, cave syndrome, } \\
\text { spinal cord compression, occlusion, } \\
\text { bleeding, or pain not controlled by } \\
\text { medical treatment }\end{array}$ & $\mathrm{H}$ & $\mathrm{H}$ & - & $\mathrm{H}$ & $\begin{array}{l}\text { Consider RT for controlling symptoms } \\
\text { (compression and bleeding). Start with } \\
\text { medical treatment (cave syndrome in } \\
\text { pulmonary CPCs). Surgery in the case } \\
\text { of cancer emergencies (spinal } \\
\text { compression, occlusion). }\end{array}$ \\
\hline Painful metastatic diseases & $\mathrm{H}$ & - & $\mathrm{H}$ & $\mathrm{H}$ & $\begin{array}{l}\text { Prefer medical treatment by analgesics, } \\
\text { chemotherapy... } \\
\text { RT for palliation if necessary. }\end{array}$ \\
\hline $\begin{array}{l}\text { Slightly progressive hormone-dependent } \\
\text { metastatic cancers }\end{array}$ & M & - & $\mathrm{L}$ & - & Start with ET. \\
\hline Follow-up appointments & Global & Surgery & $\mathrm{CT}$ & RT & Proposed multidisciplinary management. \\
\hline
\end{tabular}

Follow-up after curative treatment

$\mathrm{L}$ 
Table 2 (continued)

\begin{tabular}{lll}
\hline Clinical setting & Priority & Proposed multidisciplinary management \\
\hline & & $\begin{array}{l}\text { Follow-up by teleconsultation should be } \\
\text { preferred. Delay follow-up visits that } \\
\text { require a clinical examination (1-3 months) } \\
\text { as much as possible. }\end{array}$ \\
$\begin{array}{c}\text { Follow-up during chemotherapy or } \\
\text { endocrine therapy }\end{array}$ & M & $\begin{array}{l}\text { Postpone routine follow-up appointments } \\
\text { during ET or oral chemotherapy and } \\
\text { give priority to teleconsultations } \\
\text { for monitoring and prescription renewal. }\end{array}$ \\
& & $\begin{array}{l}\text { For asymptomatic patients, consider } \\
\text { postponing follow-up radiological } \\
\text { examinations for 1 to } 3 \text { months. }\end{array}$
\end{tabular}

$C T$, chemotherapy; $R T$, radiotherapy; $H T$, endocrine therapy. $H$, high priority: patients in need of emergency treatment; $M$, medium priority: cancer patients whose management may be delayed by 1-3 months; $F$, low priority: cancer patients whose treatment may be delayed for more than 3 months

- Favor hypo-fractionated radiotherapy protocols, in particular for breast, prostate, and rectum cancers.

Teleconsultation has become a new opportunity for triage of patients into those who should be physically examined, and those who should benefit from additional workup before their admission physically to limit their exposure to the hospital environment and therefore to reduce their risk of contamination. The main limitation of teleconsultation during follow-up is the impossibility of examining patients, but as long as the epidemic situation is not controlled, teleconsultation remains preferable [3-5, 7-9].

Therapeutic management should be discussed in an MDT meeting. The use of videoconferences is to be preferred whenever possible. If not possible, it is recommended to limit the number of participants and the duration of the MDT meetings.

\section{Modalities for Reconsidering Priority of Cancer Care During the Post-COVID-19 Era}

It is recommended to establish new schedules in order to avoid overloads of appointments (chemotherapy/radiotherapy) that may be deferred at the level of each unit. Prioritize patients in need of urgent care. Two separate situations should be considered, depending on COVID-19 status: COVID-19 negative and COVID-19 positive.

\section{Management of COVID-19-Negative Patients}

Management of COVID-19-negative patients should be discussed according to the priority of care (Table 2).

\section{Definition of Priorities [9]}

Clinical Setting of High Priority $(\mathrm{H})$ Patients with high priority have a disease which immediately threatens the vital prognosis, a clinically unstable or completely intolerable situation for which even a short delay would considerably modify the patient's prognosis.

Assuming effective treatment, these patients have priority, even if resources are limited, requiring urgent treatment to save their lives or control the progression of their illnesses or relieve their symptoms.

Clinical Setting of Medium Priority (M) Patients who do not have an immediately life-threatening disease but for whom treatment or management procedures should not be delayed more than 1-3 months without any impact on their outcomes.

Clinical Setting of Low Priority (L) Patients for whom treatment or management procedures can be postponed for more than 3 months.

\section{Examples of Certain Recommendations According to Priority (Table 2)}

\section{Urgent Treatments Which Cannot Be Postponed}

Chemotherapy Curative chemotherapy: germ cell tumors; neoadjuvant or adjuvant chemotherapy for high-risk breast cancer (HER2+ or triple-negative breast cancer); symptomatic metastatic cancers: breast cancer with visceral crisis; small cell lung carcinoma; advanced ovarian cancer, etc.

Radiotherapy Radiotherapy for emergencies: spinal cord compression, symptomatic brain metastases, bleedings, etc.; radiotherapy for locally advanced lung cancer; radiotherapy for 
locally advanced cervical cancer; locally advanced head and neck cancers; breast cancer at high risk of relapse....

\section{Treatments Which May Be Postponed for 1-3 Months}

Chemotherapy Adjuvant chemotherapy in case of intermediate-risk disease: luminal B breast cancer; colon cancer with stage $\mathrm{T} 3 \mathrm{~N} 0$ or T3N1; adjuvant chemotherapy for operable lung cancer.

Radiotherapy Adjuvant radiotherapy for intermediate-risk breast cancer: adjuvant radiotherapy for operable endometrial cancer.

\section{Management of COVID-19-Positive Patients}

A dedicated circuit should be implemented for COVID-19positive patients whose management cannot be postponed. Otherwise, management should be postponed for 4 weeks in the case of non-serious forms. In severe forms of COVID-19 disease that required a long stay in intensive care units, the management should be discussed on a case-by-case basis in a multidisciplinary team meeting after the resolution of the COVID-19 infection [1].

\section{Conclusions}

During the post-COVID-19 era, new recommendations for the management of cancer patients have been implemented in Morocco as well as in Western countries.

Medical care should ensure optimal treatment while minimizing the risk of COVID-19 transmission.

It is recommended to follow the protective measures established by the WHO to protect cancer patients from COVID-19 infection.

A national strategy for screening program of COVID-19 infection should be implemented before admission of patients in cancer centers, to protect cancer patients and medical staff.

Optimal treatment should be discussed in a multidisciplinary team meeting, and any decision made should be discussed and shared with the patient.

Management of COVID-19-negative patients should be made according to the priority of care defined by the gravity of the cancer disease.

A dedicated circuit should be implemented for COVID-19positive patients whose management cannot be postponed.
Further clinical studies are needed to guide cancer patient care during the post-COVID-19 era.

Author's contribution Nabil Ismaili contributed to the conception and design, drafting, and critical revision of this manuscript.

\section{Compliance with Ethical Standards}

Conflict of Interest The author declares that he has no conflict of interest.

Ethical Approval This article does not contain any studies with human participants performed by the author.

Consent Not applicable.

\section{References}

1. Zhang L, Zhu F, Xie L, Wang C, Wang J, Chen R, et al. Clinical characteristics of COVID-19-infected cancer patients: a retrospective case study in three hospitals within Wuhan. China Ann Oncol. 2020;31(7):894-901.

2. Jindal V, Sahu KK, Gaikazian S, Siddiqui AD, Jaiyesimi I. Cancer treatment during COVID-19 pandemic. Med Oncol. 2020;37:58.

3. Al-Shamsi HO, Alhazzani W, Alhuraiji A, Coomes EA, Chemaly $\mathrm{RF}$, Almuhanna M, et al. A practical approach to the management of cancer patients during the novel coronavirus disease 2019 (COVID19) pandemic: an international collaborative group. Oncologist. 2020;25(6):e936-45.

4. Ismaili N, El Majjaoui S. Management of breast cancer during COVID-19 pandemic in Morocco. Breast J. 2020:https://doi.org/ 10.1111/tbj.13925.

5. Ismaili N. COVID-19 and gynecological cancers: a Moroccan pointof-view. Radiother Oncol. 2020;148:227-8.

6. Toughza J, Agadr A, Ismaili N. COVID-19 and hematopoietic stem cell transplantation: Recommendations. Bull Cancer. 2020;S00074551(20):30265-4.

7. Mrabti H, Berrada N, Raiss G, Ettahri H, Abahssain H, Bourhafour $\mathrm{M}$, et al. Cancer management challenge in a developing country in COVID-19 pandemic: reflection of a group of Moroccan oncologists. Future Oncol. 2020:https://doi.org/10.2217/fon-2020-0450.

8. Canis M, Descamps P, Dubernard G, Estrade JP, Mourtialon P, Fernandez H. Gynecologic surgery in the era of COVID-19 - recommendations for deconfinement. Gynecol Obstet Fertil Senol. 2020;S2468-7189(20):30184-7.

9. Dietz JR, Moran MS, Isakoff SJ, Kurtzman SH, Willey SC, Burstein $\mathrm{HJ}$, et al. Recommendations for prioritization, treatment, and triage of breast cancer patients during the COVID-19 pandemic. The COVID-19 pandemic breast Cancer consortium. Breast Cancer Res Treat. 2020;181(3):487-97.

Publisher's Note Springer Nature remains neutral with regard to jurisdictional claims in published maps and institutional affiliations. 